\title{
COST ANALYSIS OF IMAGING DIAGNOSTIC TESTS USED IN THE MANAGEMENT OF PERIPHERAL ARTERIAL DISEASE
}

\author{
Mihaela Ioana Maris ${ }^{1}$, Sorin Ursoniu ${ }^{2, *}$, Danina Mirela Muntean ${ }^{1, *}$, Sorin Olariu ${ }^{3,4}$ and Daniela Radu ${ }^{3,4}$ \\ ${ }^{1}$ Discipline of Pathophysiology - Department of Functional Sciences, Faculty of Medicine, \\ "Center for Translational Research and Systems Medicine, "Victor Babeș" University of Medicine and Pharmacy, Timișoara, Romania \\ ${ }^{2}$ Discipline of Public Health and Health Management - Department of Functional Sciences, Faculty of Medicine, \\ Center for Translational Research and Systems Medicine, "Victor Babeș" University of Medicine and Pharmacy, Timișoara, Romania \\ ${ }^{3}$ Discipline of Surgery - Department of Surgery I, Faculty of Medicine, "Victor Babeș" University of Medicine and Pharmacy, Timișoara \\ 4"Pius Brinzeu" Emergency County Hospital, $1^{\text {st }}$ Clinic of Surgery, Timișoara, Romania

\begin{abstract}
ANALIZA TROŠKOVA VIZUELNIH DIJAGNOSTIČKIH TESTOVA U TRETMANU PERIFERNE ARTERIJSKE BOLESTI

Mihaela Ioana Maris ${ }^{1}$, Sorin Ursoniu ${ }^{2, *}$, Danina Mirela Muntean ${ }^{1, *}$, Sorin Olariu ${ }^{3,4}$ i Daniela Radu ${ }^{3,4}$

${ }^{1}$ Smer za patofiziologiju - Odsek za funkcionalne nauke, Medicinski fakultet, ${ }^{*}$ Centar za translaciona istraživanja i sistemsku medicinu Univerzitet za medicinu i farmaciju „Victor Babes“, Temišvar, Rumunija

${ }^{2}$ Smer za javno zdravlje i menadžment u zdravstvu - Odsek za funkcionalne nauke, Medicinski fakultet,

Centar za translaciona istraživanja i sistemsku medicinu, Univerzitet za medicinu i farmaciju „Victor Babes“, Temišvar, Rumunija

${ }^{3}$ Smer za hirurgiju - Odsek za hirurgiju I, Medicinski fakultet, Univerzitet za medicinu i farmaciju „,Victor Babes“, Temišvar, Rumunija
\end{abstract} \\ ${ }^{4}$ Prva hirurska klinika, Bolnica za urgentnu medicinu „Pius Brinzeu”, Temišvar, Rumunija
}

\section{ABSTRACT}

The purpose of this paper was to compare the costs of three noninvasive diagnostic investigations as the initial tests in peripheral artery disease management in Romania.

A cost analysis of three imaging diagnostic tests was performed at the university hospital in Timişoara, Romania. The tests were as follows: arterial Duplex Ultrasound Scanning, Computed Tomography Angiography, and Contrast-enhanced Magnetic Resonance Angiography. The evaluation of the diagnostic test performance was performed together with the calculation of the real costs of each investigation. Finally, an economic evaluation of different diagnostic tests was done.

A number of 46 patients (36 male and 10 female) were included in the study. The selected patients have been subjected to a total number of 61 diagnostic tests prior to the therapeutic decision. Both in terms of sensitivity and specificity, Duplex Ultrasound Scanning and Computed Tomography Angiography showed little difference in our study. The cost analysis results showed a net economic advantage if Duplex Ultrasound Scanning is applied as a diagnostic method under conditions of obtaining a similar effect.

In conclusion, Duplex Ultrasound Scanning is accurate, safe, and cost-effective in designing the final therapeutic plan in peripheral artery disease (PAD), especially in the femoropopliteal segment.

Keywords: peripheral arterial disease, Doppler duplex ultrasonography, computed tomography angiography, cost analysis

\section{SAŽETAK}

Cilj ovog rada je upoređivanje troškova tri neinvazivna dijagnostička ispitivanja kao početnih testova u tretmanu i otkrivanju perifernih arterijskih bolesti u Rumuniji.

U Univerzitetskoj bolnici u Temišvaru u Rumuniji izvršena je analiza troškova tri vizuelna dijagnostička testa. Testovi su bili sledeći: arterijski dupleks ultrazvuk, kompjuterska tomografska angiografija i kontrastno-poboljšana magnetna rezonantna angiografija. Procena učinka dijagnostičkog testa je izvršena zajedno sa izračunavanjem stvarnih troškova svakog ispitivanja. Na kraju je izvršena ekonomska evaluacija različitih dijagnostičkih testova.

U studiju je bilo uključeno 46 pacijenata (36 muškaraca i 10 žena). 46 odabranih pacijenata bilo je podvrgnuto ukupno 61-om dijagnostičkom testu pre terapijske odluke. I u smislu osetljivosti $i$ specifičnosti, Dupleks ultrazvučno skeniranje i kompjuterska angiografija pokazali su malu razliku u našoj studiji. Rezultati analize troškova pokazali su neto ekonomsku prednost ako se Dupleks ultrazvučno skeniranje primeni kao dijagnostička metoda u uslovima dobijanja sličnog efekta.

Uzaključku, Dupleks ultrazvučno skeniranje je tačno, sigurno $i$ ekonomično u dizajniranju konačnog terapeutskog plana $\mathrm{P} A B u$, posebno u femoro-poplitealnom segmentu.

Ključne reči: periferna arterijska bolest, Doppler dupleks ultrasonografija, kompjuterizovana tomografska angiografija, analiza troškova

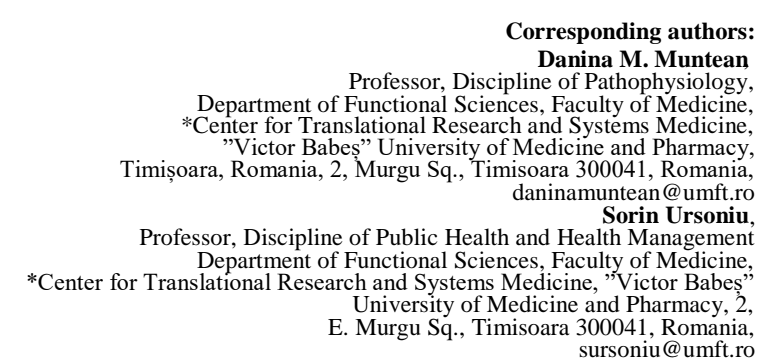

Corresponding authors: Danina M. Muntean Department of Functional Sciences, Faculty of Medicine, "Viter Translational Research and Systems Medicine, isoara 300041, Romania, Sorin Ursoniu, fessor, Discipline of Public Health and Health Management Department of Functional Sciences, Faculty of Medicine, University of Medicine and Pharmacy, 2,
E. Murgu Sq., Timisoara 300041, Romania, sursoniu@umft.ro 


\author{
ABBREVIATIONS \\ CA - Conventional Angiography \\ CE-MRA - Contrast enhancement Magnetic Resonance Angiography \\ CTA - Computed Tomography angiography \\ CMA - Cost-minimization analysis \\ DUS - Duplex Ultrasound Scanning \\ PAD - Peripheral Artery Disease
}

\section{INRODUCTION}

Cardiovascular disease was mentioned as the first cause of morbidity, with an average rate of 2557 per 10000 people. Nearly half of this rate was ischemic arterial pathology with a different location than coronary or cerebral arteries (1). According to a survey conducted by the National Agency for Health and Nutrition Examination (NHANES) in the United States in 1999-2000, there were approximately 8-10 million people with PAD. According to the same report, the PAD prevalence increases substantially with age for both genders, at a rate of 1.5-2 times per year. It has been estimated that incipient signs of PAD can be detected in $4 \%$ of the population over 40 . This prevalence increases to $14.5 \%$ for people over 70 years of age (2). People with PAD have 3 times higher risk for all causes of mortality compared to the general population (3). Patients with symptomatic PAD have a $30 \%$ risk of death within 5 years of diagnosis and almost $50 \%$ after 10 years (4). The risk of death increases in patients with more severe disease requiring surgery. Regarding the costs of treating this pathology, Medicare (the US Health Insurance System) recorded an expenditure of $\$ 4.37$ billion that has been steadily increasing over the time (5).

A patient presenting to the general practitioner with intermittent claudication has a $50 \%$ chance of getting better, $25 \%$ chances for the disease to be stationary and $25 \%$ for the disease to evolve unfavorably. Of those with unfavorable evolution, $20 \%$ will need interventions and $8-20 \%$ will undergo major amputation (6).

A preliminary diagnosis of intermittent claudication is usually done using the Edinburgh claudication questionnaire. Clinical examination in patients with PAD usually reveals a weak or absent pulse. The next step is represented by an ankle/brachial pressure index (ABPI) measurement. The patient is further investigated only if an invasive intervention is planned (7).

There are several imaging techniques that can be used to asses lower limb vasculature prior to surgery. The rapid development of new imaging techniques makes choosing one of them for preoperative assessment more difficult. Nowadays, the classical gold standard investigation represented by digital subtraction angiography has been largely replaced by less invasive techniques such as contrast-enhanced magnetic resonance angiography (CE-MRA), multirow computed tomography angiography (CTA) and color-coded duplex ultrasound scanning of the artery (DUS). In DUS stenosis is graded by the ratio between the peak systolic velocity of the targeted/stenosed vessel and adjacent or contralateral nonstenosed vessels. This index is called the peak systolic velocity ratio (PSVR). Despite the large-scale adoption of DUS in vascular disease diagnosis, its use as a single investigation before revascularization of the inferior limb remains controversial.

Nowadays, PAD management demands vascular specialists to choose both the most appropriate diagnostic tests for a clinical situation and the most cost-effectiveones.

The aim of this paper was to compare the costs of three noninvasive diagnostic investigations used in PAD management. In order to do this, we followed a three steps strategy. The first step was to assess a selected group of patients with PAD and to analyze it in terms of diagnostic tests, patients' outcome and particularities related to the management of PAD. The second step consisted of the evaluation of the diagnostic performance of the above-mentioned techniques. Finally, the third step was the economic evaluation of the diagnostic tests.

\section{PATIENTS AND METHODS}

\section{Study group}

We conducted a retrospective clinical research study on patients with suspected PAD admitted between January 2008 and July 2010 at the Clinic of Surgery belonging to the University hospital in Timișoara, Romania. The study was carried out with the agreement of the Ethics Committee of the University hospital. Out of the total number of patients with symptoms raising suspicion of ischemic arterial disease on admission (489), a total of 46 patients who met the inclusion criteria were selected.

The inclusion criteria were represented by: complete information regarding the patient and the pathology in the 
study (collected from the medical observation sheet), complete and detailed information about the diagnostic test that determined the therapeutic decision (DUS, CTA and CE-MRA), and details about patient's follow-up. For surgical patients with revascularization techniques, the reference standard was the intraoperative findings. For the remaining patients, the reference standard considered was the patients' vascular status both during hospitalization and follow-up. The minimum period of follow-up was set at six months. Cases requiring readmission, less than 30 days after discharge for treating the same lesion, were reported as cases of unfavorable evolution.

The exclusion criteria were represented by: ischemic artery disease with a different location than lower limbs, the impossibility of following patient's status for a minimum period of six months and, for non-surgical patients, the impossibility to set the reference standard. There was a single exception from these exclusion criteria represented by a patient who died eight days after the vascular intervention.

The diagnostic criterion was represented by the critical stenosis or total occlusion detected in any segment of the entire lower limb. DUS was performed with a $5 \mathrm{MHz}$ linear array transducer.
Diagnostic lesion when using DUS was considered, either an increase in PSVR of 2.5 which means a $70 \%$ reduction in the luminal diameter or absence of flow on color and power Doppler implying arterial occlusion. All CTA exams were performed on a 16 slice scanner. CE-MRA was performed on a 1.5-T imager. The decision on the appropriate treatment (revascularization procedures, amputation or conservative treatment) was made by a senior surgeon based on the reports and images of one or more (when required) of the following investigations: DUS, CTA, and CE-MRA. Revascularization procedure was chosen as the first option in the presence of no adequate outflow. When the outflow condition was poor, the option of either conservative treatment or amputation was selected according to the clinical features.

\section{Evaluation of the Diagnostic Tests Performance}

In order to assess the accuracy of the tests chosen to diagnose PAD, two reference standards were used in order to calculate the sensitivity, specificity, positive and negative predictive values, accuracy and classification error rate. The $2 \times 2$ tables of test performance/contingency (Table 1) were used in order to calculate the following indicators:

Table 1.Contingency table assessing test performance.

\begin{tabular}{|c|c|c|c|c|}
\hline \multirow{2}{*}{\begin{tabular}{c} 
Reference standard \\
\multirow{2}{*}{$\begin{array}{c}\text { demonstrating the state of the } \\
\text { disease }\end{array}$}
\end{tabular}} & D+ & $\begin{array}{c}\text { The evaluated test } \\
\text { (TP) }\end{array}$ & $\begin{array}{c}\text { False negative } \\
\text { (FN) }\end{array}$ & \multirow{2}{*}{ No D+ } \\
\cline { 3 - 5 } & D- & $\begin{array}{c}\text { False positive } \\
(\mathrm{FP})\end{array}$ & $\begin{array}{c}\text { True negative } \\
(\mathrm{TN})\end{array}$ & No D- \\
\hline & & No T+ & No T- & Total No \\
\hline
\end{tabular}

Sensitivity - proportion of people with affection who have a positive test

$$
\Rightarrow S N=\mathrm{TP} /(\mathrm{TP}+\mathrm{FN})=\mathrm{TP} / \mathrm{No} \mathrm{B}+
$$

Specificity - proportion of people without affection who have a negative test

$$
\Rightarrow \boldsymbol{S P}=\mathrm{TN} /(\mathrm{TN}+\mathrm{FP})=\mathrm{TN} / \mathrm{No} \mathrm{D}-
$$

Positive prediction value - proportion of people testing positive that have the condition

$$
\Rightarrow \boldsymbol{P P} \boldsymbol{V}=\mathrm{TP} /(\mathrm{TP}+\mathrm{FP})=\mathrm{TP} / \mathrm{No} \mathrm{T}+
$$

Negative prediction value - proportion of people testing negative that do not have the condition

$$
\Rightarrow \boldsymbol{N P V}=\mathrm{TN} /(\mathrm{FN}+\mathrm{TN})=\mathrm{TN} / \mathrm{No} \mathrm{T}-
$$

Accuracy $=>\boldsymbol{A C}=(\mathrm{TP}+\mathrm{TN}) /$ Total No

$$
\text { Classification error rate }=>\boldsymbol{E} \boldsymbol{R}=(\mathrm{FN}+\mathrm{FP}) / \text { Total No }
$$

As convention recommended by Moses et al, for all cells with a value of zero, when calculating the indicators, a value of 0.5 was added (8).

\section{Economic Evaluation of Three Diagnostic Tests Used in} Deciding PAD Management

The choice of diagnostic test goes far beyond a simple assessment of the performances of an individual assay. In order to be able to choose the best diagnostic test, other aspects, such as patients' disease outcome and cost analysis should be considered.

In this respect, it is necessary to calculate the costs of the investigation and the general formulas for computing the real cost/investigation, regardless of the type of diagnostic test, are presented in Table 2 . 
Table 2. The general formulas for calculating the real cost/investigations

Operational costs/month =
Direct medical expenses + Indirect medical expenses + Non-medical expenses (when appropriate)

\section{Direct medical expenses $=$}

Expenditure on wages + Expenditure on materials + Capital costs (damping + wear/depreciation + maintenance service of the investigation equipment)

\section{Indirect medical expenses =}

Overhead/General costs (facility space cost, utilities, energy, etc) + Ancillary expenses (with staff not directly involved in the execution of the service - cleaning, porters, medical records, accounting service, office supplies)

\section{Real cost/investigation $=$}

Operational costs per month/number of working days per month/number of working hours per day/number of investigations per hour

Directly assignable costs included personnel costs, material costs (contrast agents, syringes, etc) and equipment costs. Personnel costs were calculated based on the estimated time spent performing a certain type of diagnostic test per month and the mean wages for each involved personnel category (including $43 \%$ tax charges). Costs of materials were calculated based on cost prices and summed for each test. The capital/equipment costs consisted of annual costs of imaging equipment and the annual costs of equipment maintenance. The costs for radiology equipment were computed using the annuitization method with a 5\% annual discount/interest (9).

Depreciation of medical devices was made in accounting for a period of 5 years. The costs of maintenance of the equipment were $5 \%$ /year. The costs of radiology equipment as well as the costs of equipment maintenance were divided by the proportion of total available room time ( $80 \%$ of a 160 -hour work month) (10). Overhead/general costs have been calculated by estimating the costs of utilities, energy, special location conditions. Ancillary costs were not included because they were approximately equal in all three radiology tests studied.
Regarding the economic aspects involved in choosing the preferred diagnostic test, a cost-minimization analysis (CMA) was performed.

CMA measures and compares input costs when the outcomes of two or more options are assumed to be equivalent. This type of economic evaluation is often seen as being "Cinderella" of the Cost-effectiveness analysis. Many analysts consider this method a simple cost analysis. The difference between the two is represented by the fact that, when running a CMA, all possible consequences have to be highlighted and compared, and only if the differences among them are considered insignificant, the analysis can be performed (11).

The cost side of a CMA equation is equivalent to that of the other methods used in Cost-effectiveness analysis. In CMA, the least expensive option is preferred. The results of the analyzed options can be compared in the matrix presented in Table 3 (9).

Table 3. Matrix for CMA comparison (9)

\begin{tabular}{|c|c|c|c|c|c|c|}
\hline & & & \multicolumn{4}{|c|}{$\begin{array}{l}\text { Incremental effectiveness of option compared } \\
\text { to control }\end{array}$} \\
\hline & & & \multicolumn{2}{|c|}{ More } & Same & Less \\
\hline \multirow{3}{*}{\multicolumn{2}{|c|}{$\begin{array}{l}\text { Incremental cost of the option } \\
\text { compared to control }\end{array}$}} & More & \multicolumn{2}{|c|}{7} & 4 & 2 \\
\hline & & Same & \multicolumn{2}{|c|}{3} & 9 & 5 \\
\hline & & Less & \multicolumn{2}{|c|}{1} & 6 & 8 \\
\hline $\begin{array}{l}\text { Strong dominance for } \\
\text { decision }\end{array}$ & \multicolumn{3}{|c|}{$\begin{array}{l}\text { Weak domination for } \\
\text { decision }\end{array}$} & \multicolumn{3}{|c|}{$\begin{array}{l}\text { Non-dominance: } \\
\text { no obvious decisions }\end{array}$} \\
\hline $\begin{array}{l}\mathbf{1}=\text { accept option } \\
\mathbf{2}=\text { reject option }\end{array}$ & \multicolumn{3}{|c|}{$\begin{array}{l}\mathbf{3}=\text { accept option } \\
\mathbf{4}=\text { reject option } \\
\mathbf{5}=\text { reject option } \\
\mathbf{6}=\text { accept option }\end{array}$} & \multicolumn{3}{|c|}{$\begin{array}{l}\mathbf{7}=\text { Does added effect deserve added cost to adopt } \\
\text { the option? } \\
\mathbf{8}=\text { Is the reduced effect acceptable, given } \\
\text { reduced cost to adopt the option? } \\
\mathbf{9}=\text { Neutral on costs and effects, other reasons } \\
\text { to adopt the option? }\end{array}$} \\
\hline
\end{tabular}




\section{RESULTS}

\section{Patients' Characteristics}

A number of 46 patients (36 male and 10 female) were included in the present study and the general characteristics (distribution by gender and age) of the patients are presented in Figure 1.

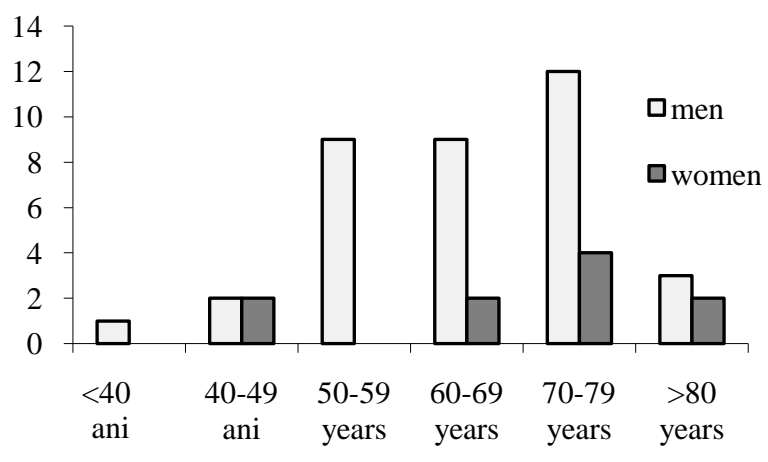

Figure 1.

The diagnostic tests studied in our research were represented by arterial DUS for all the years of the study, CTA mainly for 2009 and 2010, and CE-MRA only for 2008. The type of diagnostic lesion was considered critical stenosis (>70\% stenosis) or total occlusion detected in any segment of the lower limbs. The 46 patients selected have been subjected to a total number of 61 diagnostic tests prior to the therapeutic decision. During the hospitalization, the surgical patients were subjected to at least three evaluation exams while the medical ones have received at least one DUS evaluation. Regarding the follow-up period, the patients were examined at least twice with arterial DUS. The distribution of patients with suspected PAD lesions with respect to the diagnostic investigations was as follows: 32 patients were diagnosed with only one type of examination, while in 14 cases the diagnosis was based on information obtained by combining two or all three investigations (Figure 2).

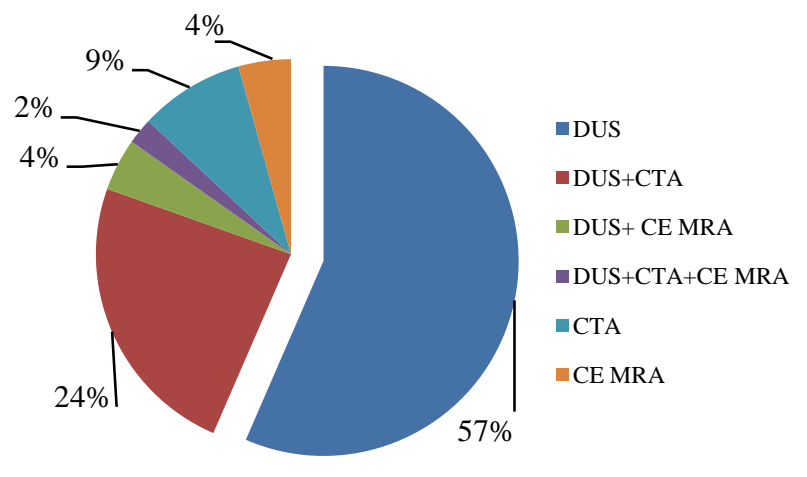

Figure 2.

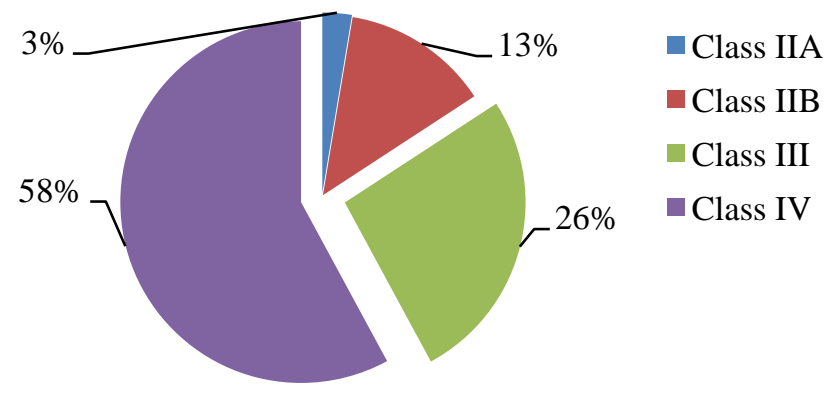

Figure 3.

Based on the results from diagnostic tests, 38 patients were diagnosed with critical stenosis or total occlusion in one or more segments of the lower limb. According to the LericheFontaine classification, our study group was classified as shown in Figure 3 (12).

As we have already mentioned, the patients were differentiated not only on the basis of the diagnostic examination, but also on the type of therapeutic intervention (Figure 4).

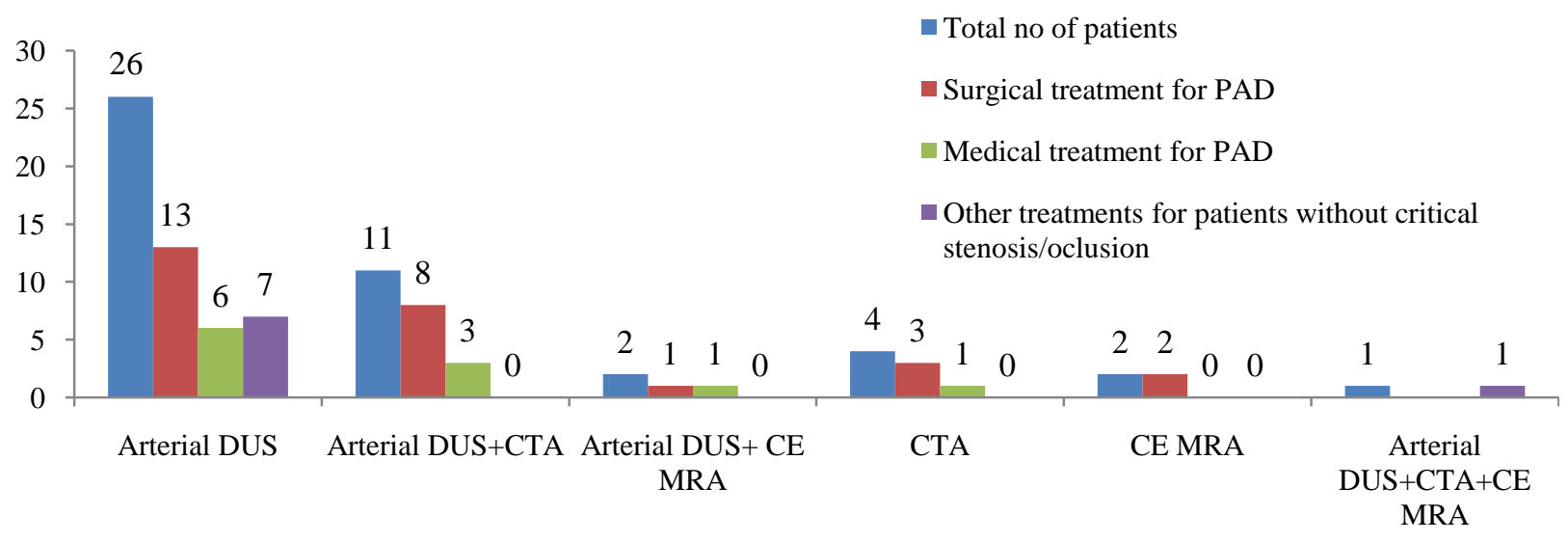

Figure 4. 
The lower percentage of surgical cases in the group examined with DUS was determined by the fact that in 7 cases DUS, in fact, excluded the presence of a critical stenosis/occlusion. Out of the 38 patients diagnosed with critical stenosis/occlusion of a lower limb artery, 10 patients (29\%) underwent medical treatment and the 28 patients underwent the following types of arterial surgery: $47 \%$ revascularization procedures, $16 \%$ primary amputations, $8 \%$ sympathectomies.

Based on the information presented in Table 4, we can draw conclusions about patient outcomes. As it can be seen, the percentage of surgical patients in the total number of PAD patients analyzed varied from $50 \%$ to $100 \%$ and appeared to be more related to the severity of the lesions than to the type of diagnostic test. The highest percentage of primary major amputations was recorded in the group investigated exclusively by CTA $(33.3 \%)$. Cases requiring major amputations after the initial revascularization intervention were recorded in the DUS+CTA group (2 cases), DUS+CE-MRA group (1 case), and DUS group (2 cases). The highest percentage was recorded in the DUS+CTA group (22.2\%). The percentage representing both primary and secondary major amputations was approximately $30 \%$. Adverse developments recorded in the same hospitalization or the need for readmission to solve the same lesion was recorded both in the DUS group and in the DUS+CTA and DUS+CE-MRA. These paradoxically negative evolutions appeared to be the consequence of the PAD evolution rather than the applied diagnostic method.

Table 4. Patient outcomes

\begin{tabular}{|c|c|c|c|c|c|}
\hline Intervention/Investigation & DUS & CTA & CE MRA & DUS+CTA & $\begin{array}{l}\text { DUS+CE } \\
\text { MRA }\end{array}$ \\
\hline Surgical patients & $\begin{array}{c}(13 / 19) \\
68 \%\end{array}$ & $\begin{array}{l}(3 / 4) \\
75 \%\end{array}$ & $\begin{array}{l}(2 / 2) \\
100 \%\end{array}$ & $\begin{array}{c}(8 / 11) \\
72.72 \%\end{array}$ & $\begin{array}{l}(1 / 2) \\
50 \%\end{array}$ \\
\hline Revascularization techniques & $\begin{array}{l}(8 / 13) \\
61.5 \%\end{array}$ & $\begin{array}{l}(2 / 3) \\
66.6 \%\end{array}$ & $\begin{array}{l}(2 / 2) \\
100 \%\end{array}$ & $\begin{array}{l}(5 / 8) \\
62.5 \%\end{array}$ & $\begin{array}{l}(1 / 1) \\
100 \%\end{array}$ \\
\hline Lumbar+/-Periarterial Sympathectomy & $\begin{array}{l}(1 / 13) \\
7.6 \% \\
\end{array}$ & 0 & 0 & $\begin{array}{l}(2 / 8) \\
25 \% \\
\end{array}$ & 0 \\
\hline Primary minor amputation & $\begin{array}{l}(1 / 13) \\
7.6 \%\end{array}$ & 0 & 0 & 0 & 0 \\
\hline Primary major amputation & $\begin{array}{l}(3 / 13) \\
23 \%\end{array}$ & $\begin{array}{c}(1 / 3) \\
33.3 \%\end{array}$ & 0 & $\begin{array}{c}(1 / 8) \\
12.5 \%\end{array}$ & 0 \\
\hline $\begin{array}{l}\text { Major amputation (secondary to } \\
\text { revascularization) }\end{array}$ & $\begin{array}{l}(1 / 13) \\
7.6 \% \\
\end{array}$ & & & $\begin{array}{l}(2 / 8) \\
25 \%\end{array}$ & $\begin{array}{l}(1 / 2) \\
50 \%\end{array}$ \\
\hline Major amputation (primary+secondary) & $30.7 \%$ & $33.3 \%$ & & $37.5 \%$ & 50 \\
\hline Stage IV Leriche-Fontaine & $\begin{array}{c}(13 / 19) \\
68 \%\end{array}$ & $(3 / 4) 75 \%$ & & $\begin{array}{c}(5 / 11) \\
45.45 \%\end{array}$ & $\begin{array}{l}(1 / 2) \\
50 \%\end{array}$ \\
\hline $\begin{array}{l}\text { Average no days/hospitalization surgical } \\
\text { patients }\end{array}$ & 23.69 & 26.66 & 20 & 37.77 & 8 \\
\hline $\begin{array}{l}\text { Average no days/hospitalization medical } \\
\text { patients }\end{array}$ & 10.5 & 4 & & 17.66 & 20 \\
\hline
\end{tabular}

The number of days of hospitalization was constantly higher for patients who underwent surgery (average no days/hospitalization=27.35) than those who received drug therapy (average no days/hospitalization=12.72).

\section{Assessment of Diagnostic Accuracy in the Critical Ste- nosis/Occlusion of Lower Limb Arteries}

In order to establish the investigations accuracy in diagnosing PAD, we compared the results for the abovementioned tests. For all three selected tests, the contingency tables are presented in Tables 5, 6 and 7 .
Table 5. Contingency table assessing DUS performance

\begin{tabular}{|c|c|c|c|c|}
\cline { 3 - 4 } \multicolumn{2}{c|}{} & \multicolumn{3}{c|}{ Arterial DUS } \\
\cline { 3 - 4 } \multicolumn{2}{c|}{} & $\mathrm{T}+$ & $\mathrm{T}-$ & \multicolumn{1}{c}{} \\
\hline \multirow{2}{*}{$\begin{array}{c}\text { Reference } \\
\text { standard for } \\
\text { disease }\end{array}$} & $\mathrm{D}+$ & 29 & 2 & 31 \\
\cline { 2 - 5 } & $\mathrm{D}-$ & $0(0.5)$ & 9 & 9 \\
\hline \multicolumn{2}{|c}{} & 29 & 11 & 40 \\
\hline
\end{tabular}


Table 6. Contingency table assessing CTA performance

\begin{tabular}{|c|c|c|c|c|}
\hline & & \multicolumn{2}{|c|}{$C T A$} & \\
\hline & & $\mathrm{T}+$ & T- & \\
\hline \multirow{2}{*}{$\begin{array}{c}\text { Reference } \\
\text { standard for } \\
\text { disease }\end{array}$} & $\mathrm{D}+$ & 14 & 1 & 15 \\
\hline & D- & $0(0.5)$ & 1 & 1 \\
\hline & & 14 & 2 & 16 \\
\hline
\end{tabular}

Table 7. Contingency table assessing CE MRA performance

\begin{tabular}{|c|c|c|c|c|}
\cline { 3 - 5 } \multicolumn{2}{c|}{} & \multicolumn{2}{c|}{ CE MRA } & \multicolumn{1}{|c}{} \\
\cline { 3 - 5 } \multicolumn{2}{c|}{} & $\mathrm{T}+$ & $\mathrm{T}-$ & \\
\hline $\begin{array}{c}\text { Reference } \\
\text { standard for } \\
\text { disease }\end{array}$ & $\mathrm{D}+$ & 4 & $0(0.5)$ & 4 \\
\cline { 2 - 5 } & $\mathrm{D}-$ & $0(0.5)$ & 1 & 1 \\
\hline \multirow{2}{*}{} & & 4 & 1 & 5 \\
\hline
\end{tabular}

After computing the quality indicators for each diagnostic test, a comparison was performed to assess the accuracy (Table 8). Only the indicators for CE-MRA could not be considered reliable view the low number $(<10)$ of assay performed (13).

Regarding the sensitivity, no significant difference was found between arterial DUS and CTA in the present study
(93.5\% vs. 93.3\%). Similarly, no differences were found with respect to specificity for all three diagnostic tests.

Economic Evaluation of the Diagnostic Tests Used in PAD Management

The prices of diagnostic tests show rather large variation between the state system (i.e., the amount paid by the National Health Insurance system) and the private one, respectively. As neither of these prices are reflecting the real costs of the services, the real cost of the diagnostic tests used was computed. The cost assessment was performed from a health care provider perspective using the 2009 unit costs data in Euros $(€)$, using the RON currency conversion when needed.

The applied exchange rate was $€ / \mathrm{RON}=1 / 4.21$ (14).

No discount rate was applied due to the fact that the study was conducted for a period of less than five years.

The real costs calculated for DUS, CTA and CE-MRA are presented in Table 9 whereas a detailed explanation of these costs and prices is presented in Table 10 as follows: the real cost/investigation calculated in this paper and the other two prices, the one settled by the National Health Insurance (15) and the other settled by private practices (16) showing clear differences in prices among the analyzed imaging assays. There is a neat economic advantage if DUS is applied as a diagnostic method. Regarding the effect/consequences, we analyzed in this paper both performances of the tests and patients' outcomes.

Table 8. The quality indicators

\begin{tabular}{|l|c|c|c|}
\hline Indicator & DUS & CTA & MRI angiography \\
\hline Sensitivity/SN & $93.5 \%$ & $93.3 \%$ & $80 \%$ \\
\hline Specificity/SP & $100 \%$ & $100 \%$ & $100 \%$ \\
\hline Positive prediction value/PPV & 1 & 1 & 1 \\
Negative prediction value/NP & 0.81 & 0.5 & 1 \\
Accuracy/AC & $95 \%$ & $93.7 \%$ & $100 \%$ \\
Classification error rate/ER & $6.2 \%$ & $9.3 \%$ & $30 \%$ \\
\hline
\end{tabular}

Table 9. Real costs of DUS, CTA and CE-MRA.

\begin{tabular}{|l|}
\hline $\begin{array}{l}\text { Real cost/investigation }=\text { Operational costs per month/20 working days per month/6 working hours per day/1 } \\
\text { investigation per hour }\end{array}$ \\
$\Rightarrow(1664+30+837+1000) / 20 \times 6 \times 1=3531 / 120$ \\
$\Rightarrow \mathbf{2 9 . 4 3} €$ \\
\hline $\begin{array}{l}\text { Real cost/investigation }=\text { Operational costs per month/20 working days per month/6 working hours per day/2 } \\
\text { investigations per hour }\end{array}$ \\
$\Rightarrow(2683+5890+6088+5000) / 20 \times 6$ × $2=19661 / 240$ \\
$\Rightarrow \mathbf{8 1 . 9 2} €$ \\
\hline $\begin{array}{l}\text { Real cost/investigation }=\text { Operational costs per month/20 working days per month/6 working hours per } \\
\text { day/1.5 investigations per hour }\end{array}$ \\
$\Rightarrow(2683+4625+17561+4000) / 20 \times 6 \times 1,5=28869 / 210$ \\
$\Rightarrow \mathbf{1 6 0 . 3 8} €$
\end{tabular}


Table 10. Detailed costs and prices for DUS, CTA and CE MRA

\begin{tabular}{|c|c|c|c|}
\hline & DUS & CTA & CEMRA \\
\hline Expenditure on labor/personnel/month & $1664 €$ & $2638 €$ & $2638 €$ \\
\hline Expenditure on materials/month & $30 €$ & $5890 €$ & $4625 €$ \\
\hline Expenditure on investigation equipment/month & $837 €$ & $6088 €$ & $17561 €$ \\
\hline Expenditure on utilities, rent, etc. & $1000 €$ & $5000 €$ & $4000 €$ \\
\hline $\begin{array}{l}\text { Real cost/investigation = Operational costs per } \\
\text { month/20 working days per month/6 working } \\
\text { hours per day/1 (DUS), 2(CTA), } 1.5 \text { (CE MRA) } \\
\text { investigations per hour }\end{array}$ & $\begin{aligned}= & 29.43 € \\
& \sim 30 €\end{aligned}$ & $\begin{aligned}= & 81.92 € \\
& \sim 82 €\end{aligned}$ & $\begin{aligned}= & 160.38 € \\
& \sim 161 €\end{aligned}$ \\
\hline $\begin{array}{l}\text { Prices for arterial DUS, CTA, CE MRA in } \\
\text { private system (15) }\end{array}$ & $\sim 43 €$ & $\sim 131 €$ & $\sim 162 €$ \\
\hline $\begin{array}{l}\text { Maximum rate paid by the Romanian Health } \\
\text { Insurance House per investigation (16) }\end{array}$ & $\sim 4.7 €$ & $\sim 60 €$ & $\sim 95 €$ \\
\hline
\end{tabular}

The final step consisted of combining the conclusions on similar patient outcomes when applying different diagnostic test with the results of similar sensibility and specificity for DUS and CTA ( 93\%, 100\%) and, finally, with the calculated real cost/investigation $(30 €, 82 €)$ in a CMA matrix.
The outcomes of our approach can be classified in a CMA matrix as "The same incremental effectiveness of option compared to control and a less incremental cost of the option compared to control". This means "Accept option with weak domination for the decision" (9).

\section{DISCUSSION}

When choosing a diagnostic test, the cost, availability, acceptability, and usefulness of the diagnostic test must be taken into account in addition to the test performance. Knottnerus et al. proposed a strategy based on diagnostic performance, availability and acceptability, and, last but not least, its cost (17). Our study followed this strategy.

Firstly, we assessed the performance/accuracy of DUS compared to CTA and CE MRA. Regarding DUS and CTA, the values obtained in our study (Table 11) are consistent with those reported within a systematic review by Collins et al. that analyzed and compared the diagnostic accuracy for the assessment of critical limb stenosis/occlusion by means of DUS (20 studies), CTA (11 studies), and CE-MRA (17 studies), respectively (6).

Table 11. Performance indicators for DUS, CTA and CE-MRA

\begin{tabular}{|l|c|c|c|}
\hline Diagnosis test & DUS & CTA & CE MRA \\
\hline $\begin{array}{l}\text { Sensitivity/SN (literature) } \\
\text { Median (interval) }\end{array}$ & $\begin{array}{c}90 \% \\
(74 \% \text { la } 94 \%)\end{array}$ & $\begin{array}{c}97 \% \\
(89 \% 1 \mathrm{la} 100 \%)\end{array}$ & $\begin{array}{c}94 \% \\
(85 \% 100 \%)\end{array}$ \\
\hline $\begin{array}{l}\text { Specificity/SP (literature) } \\
\text { Median (interval) }\end{array}$ & $99 \%$ & $99,6 \%$ & $99,2 \%$ \\
$(96 \% 1 \mathrm{la} 100 \%)$ & $(99 \%$ la $100 \%)$ & 17 \\
\hline Included studies & 20 & 11 & $100 \%$ \\
\hline Sensitivity/SN in our study & $93,5 \%$ & $93,3 \%$ & $100 \%$ \\
\hline Specificity/SP in our study & $100 \%$ & $100 \%$ & $17 \%$ \\
\hline
\end{tabular}


According to their and our results, both DUS and CTA represent a good alternative to conventional angiography (CA). This conclusion was made only on the bases of the test performance. As for the discrepancies observed in the CEMRA analysis, these are the effect of the small sample size, only 5 assays being performed.

Diagnostic performance/accuracy studies are neither able to compare tests on their final impact on patient outcomes nor to provide cost-effectiveness information.

Because high diagnostic accuracy does not always reflect in the clinical usefulness, the DUS ability to define treatment plans must be proven. There are several studies that have demonstrated the reliability of DUS in establishing the final treatment strategy in PAD $(6,17-22)$.

Data available regarding the confidence and reproducibility of DUS in the PAD management are controversial. A number of studies indicated a low confidence score obtained by DUS as compared to CE-MRA or CTA $(23,24)$. Concerning the reproducibility of DUS results and the achievement of a higher inter-observer agreement, the literature is stating that a consensus is required with respect to the hemodynamic relevance of stenosis versus the degree of stenosis $(20,6)$.

Availability, acceptability and costs are all important issues that need to be considered when choosing a diagnostic test. Our study was conducted at the University hospital where all the above mentioned diagnostic tests (DUS, CTA, CERMA, CA) were available. In terms of patient acceptability, DUS is particularly preferred view its non-invasive nature.

The real cost of the investigation for each of the diagnostic test examined (wages, material and contrast medium, capital costs, overheads) was calculated. Our findings are consistent with other studies that have used decision analysis models (25). Moreover, when applying CMA, a similar conclusion was reported by Collins et al (6).

\section{Limitations of the study}

The small sample of only 46 patients led to discrepancies with respect to the results regarding the diagnostic accuracy for CE-MRA versus data reported in the literature.

The cost analysis focused on the investigation costs without adding costs for applied surgical procedures or hospitalization. The only way to calculate the cost of hospitalization with surgical/medical treatment (hospital stay, surgical procedure, anesthesiology, intensive care, and clinical laboratory) was based on diagnosis-related group (DRG) prices that the National Health Insurance system paid for each case resolved. This cost was the same for all surgical/medical patients, without any difference related to the type of intervention suffered, the number of days of hospitalization or other differences between cases. Adding this cost would not help our intention to make a difference between the cases investigated by one or the other diagnostic test.
Also, no summary benefit measure was done; only individual clinical outcomes were reported.

\section{CONCLUSIONS}

DUS is accurate, safe and cost-effective in designing the final therapeutic plan for PAD, especially in the femoropopliteal segment provided that it is performed by an experienced specialist in a clinic with solid expertise in this respect. The present study will be used as a reference to future address the reliability in time of DUS in terms of cost- effectiveness in our hospital.

\section{ACKNOWLEDGMENTS}

None

\section{REFERENCES}

1. Petersen S, Peto V, Rayner M, Leal J, Luengo-Fernandez R \& Gray A. (2005). European Cardiovascular Disease Statistics: London: British Heart Foundation.

2. Selvin E \& Erlinger TP. (2004). Prevalence of and risk factors for peripheral arterial disease in the United States: results from the National Health and Nutrition Examination Survey, 1999-2000. Circulation, 110(6), 738-743. DOI:10.1161/01.CIR.0000137913.26087.F0

3. Criqui MH, Langer RD, Fronek A, Feigelson HS, Klauber MR, McCann TJ \& al. (1992). Mortality over a period of 10 years in patients with peripheral arterial disease. N Engl J Med, 326(6), 381-386. DOI:10.1056/NEJM199 202063260605

4. Tierney S, Fennessy F \& Hayes D. (2000). Secondary prevention of peripheral vascular disease. BMJ, 320, 1262-5. PMID:10797042. PMCID:PMC1117996

5. Hirsch AT, Hartman L, Town RJ \& Virnig BA. (2008). National health care costs of peripheral arterial disease in the Medicare population. Vasc Med, 13(3), 209-215. DOI:10.1177/1358863X08089277

6. Collins R, Burch J, Cranny G \& al. (2007). Duplex ultrasonography, magnetic resonance angiography, and computed tomography angiography for diagnosis and assessment of symptomatic, lower limb peripheral arterial disease: systematic review. BMJ, 334, 1257. DOI:10.1136/ bmj.39217.473275.55

7. Burns P, Gough S \& Bradbury AW. (2003). Management of peripheral arterial disease in primary care. BMJ, 326, 585-8. DOI:10.1136/bmj.326.7389.584

8. Moses L, Shapiro D \& Littenberg B. (1993). Combining independent studies of a diagnostic test into a summary ROC curve: data-analytic approaches and some additional considerations. Stat Med, 12, 1293-316. PMID:8210827 
9. Drummond MF, Sculpher MJ, Torrance GW, O'Brien BJ $\&$ Stoddart GL. (2005). Methods for the Economic Evaluation of Health Care Programmes. Third Edition. Great Britain: Oxford University Press.

10. Hunink MG \& Glasziou PP. (2001). Decision making in health and medicine: integrating evidence and values. Cambridge, England: Cambridge University Press.

11. Vladescu C, Ursoniu S, Ciobanu V, Bucur A, Bucur A \& al. (2004). Sanatate publica si management sanitar. Bucuresti: Cartea universitara.

12. Hardman RL, Jazaeri O, Yi J, Smith M \& Gupta R. (2014). Overview of Classification Systems in Peripheral Artery Disease. Semin Intervent Radiol, 31(4), 378-388. DOI: $10.1055 / \mathrm{s}-0034-1393976$

13. Bujang MA \& Adnan TH. (2016). Requirements for Minimum Sample Size for Senzitivity and Specificity Analysis. J Clin Diagn Res, 10(10), YE01-YE06. DOI: 10.7860/JCDR/2016/18129.8744

14. RON currency conversion www.cursbnr.ro/arhiva-cursbnr-2009-07-31

15. Prices for arterial DUS, CTA, CE MRA in private system www.cardioclinic.ro

16. Maximum rate paid by the Romanian Health Insurance House www.cjastm.ro

17. Knottnerus JA, Muris JW. (2003). Assessment of the accuracy of diagnostic tests: the crosssectional study. J Clin Epidemiol, 56, 1118-1128. PMID:14615003

18. Wong TH, Tay KH, Sebastian MG \& Tan SG. (2013) Duplex ultrasonography arteriography as first-line investigation for peripheral vascular disease. Singapore Med J, 54. 271-4. PMID:23716153

19. Aly S, Shoab S \& Bishop C. (1999). Inter-observer variation. An alternative method of assessing the role of ultra- sonic imaging in clinical decision-making in lower limb arterial disease. Int Angiol, 18, 220-4. PMID:10688421

20. Koelemay MJ, den Hartog D, Prins MH, Kromhout JG, Legemate DA \& Jacobs MJ. (1996). Diagnosis of arterial disease of the lower extremities with duplex ultrasonography. Br J Surg, 83, 404-9. PMID:8665208

21. Elsman BH, Legemate DA, van der Heijden FH, de Vos HJ, Mali WP \& Eikelboom BC. (1995). Impact of ultrasonographic duplex scanning on therapeutic decision making in lower-limb arterial disease. Br J Surg, 82, 6303. https://doi.org/10.1002/bjs. 1800820518

22. Grassbaugh JA, Nelson PR, Rzucidlo EM \& al. (2003). Blinded comparison of preoperative duplex ultrasound scanning and contrast arteriography for planning revascularization at the level of the tibia. J Vasc Surg, 37, 11861190. doi.org/10.1016/S0741-5214(03)00328-8

23. Visser K \& Hunink MG. (2000). Peripheral arterial disease: gadolinium enhanced MR angiography versus color-guided duplex US a meta-analysis. Radiology, 216, 67-77. DOI:10.1148/radiology.216.1.r00j10367

24. de Vos MS, Bol BJ, Gravereaux EC, Hamming JF \& Nguyen LL. (2014). Treatment planning for peripheral arterial disease based on duplex ultrasonography and computed tomography angiography: consistency, confidence and the value of additional imaging. Surgery, 156, 492-502. DOI:10.1016/j.surg.2014.03.035

25. Visser K, Kuntz KM, Donaldson MC, Gazelle GS \& Hunink MG. (2003). Pretreatment imaging workup for patients with intermittent claudication: a costeffectiveness analysis. J Vasc Interv Radiol, 14, 53-62. PMID: 12525586 